\title{
Studies on phytopathogenic and saprotrophic fungi in rush associations of Lake Glinno (NW Poland)
}

\author{
KINGA MAZURKIEWICZ ZAPAEOWICZ1', MARIOLA WRÓBEL ${ }^{2}$, \\ ARTUR SILICKI ${ }^{1}$ and MARIA WOLSKA ${ }^{1}$ \\ ${ }^{1}$ Department of Hydrobiology, University of Agriculture, K. Królewicza 4 \\ PL 71550 Szczecin, zapalowicz@fish.ar.szczecin.pl \\ ${ }^{2}$ Department of Botany and Nature Protection, University of Agriculture, Słowackiego 17 \\ PL 71434 Szczecin, mwrobel@agro.ar.szczecin.pl
}

Mazurkiewicz Zapałowicz K., Wróbel M., Silicki A., Wolska M.: Studies on phytopathogenic and saprotrophic fungi in rush associations of Lake Glinno (NW Poland). Acta Mycol. 41 (1): 125 138, 2006.

During the vegetation seasons in years 20042005 the health state of rush plant species from Phragmition and Magnocaricion alliances around the Lake Glinno was investigated. From 13 plant species with disease symptoms 94 species of fungi and FLO were isolated. The highest mycological biodiversity was stated in Phragmitetum australis (24 species) and Thelypteridi Phragmitetum (27 species) plant associations. The host species in which the biggest number of fungi and FLO species was observed were: Phragmites australis (37 species) and Carex acutiformis (25 species). The highest mycological similarity based on the Jaccard Sörensen coefficient occurred between Caricetum acutiformis and Glycerietum maximae plant associations $(50 \%)$ whereas the lowest value of the coefficient represented Glycerietum maximae and Phalaridetum arundinaceae associations (7\%).

Key words: rush associations; saprotrophic and phytopathogenic fungi

\section{INTRODUCTION}

Rush vegetation represents a common object of both phytosociological (Tomaszewicz 1978; Kreft, Truchan 1996; Wołejko 2000; Bosiacka, Radziszewicz 2002) or ecological (Szczepański 1978; Marks, Randall 1994; Boszke et al. 2005) studies in Poland. Sporadic reports, on the other hand, focus on phytosanitary condition of these plants or deal with fungus-like organisms (FLO) or fungi that accompany rush associations and affect their health during their growth. The literature on this subject concern primarily Phragmites australis (Durska 1970; Mułenko 1989; Adamska, Błaszkowski 2000; Mazurkiewicz-Za pałowicz et al. 2005). Microscopic fungi phytopathogenic to other plants that are characteristic or distinctive for rush associations have been studied at the Łęczna-Włodawa Lake District (Mułenko 1989). To date, the fungal biodiversity 
related to diversification of large-area Phragmitetea-class rush phytocenoses has not been described in Poland. Hence, these studies were undertaken in order to learn the distribution of both phytopathogenic and saprotrophic fungi and FLO accompanying the growth of plants in various rush communities located around Lake Glinno. These are the first studies aimed at characterization of the condition of rush associations in the region of Western Pomerania, Poland.

\section{MATERIAL AND METHODS}

The studies were carried out during the vegetation seasons of 2004 and 2005. The material was collected four times a year on five sites located along the bank of Lake Glinno, where typical patches of rush vegetation had formed, represented by Phragmitetea r.tx. et prsg 1942 class and Phragmitetalia Koch 1926 order with two alliances, Phragmition and Magnocaricion. The Phragmition alliance reed beds are characterised by poor floristic composition and a wide ecological amplitude of the species comprising such phytocenoses. These are found mainly on the banks of eutrophic bodies of still or sluggish water within the transition zone between the communities of Potametea class floating hydrophytes and the large sedges of the Magnocaricion association. On the other hand, either natural or anthropogenic communities of bog vegetation and large sedges classified within the Magnocaricion alliance inhabit slightly more elevated riparian zones that, compared to reed beds, are flooded less frequently and, if so, remain submerged for shorter periods of time (Matuszkiewicz 2001).

In Phragmition alliance were distinguished 3 plant associations: Eleocharitetum palustris Sennikov 1919, Phragmitetum australis Gams 1927 Schmale 1939 and Glycerietum maximae Hueck 1931 as well as four ones from Magnocaricion alliance: Caricetum acutiformis Sauer 1937, Phalaridetum arundinaceae (Koch 1926) Lib.1931, Thelypteridi-Phragmitetum Kuiper 1957 and Caricetum ripariae Soo 1928. The associations were distinguished by means of 9 phytosociological relevés applying the Braun-Blanquet method (Szafer, Zarzycki 1977), whereas the taxonomy of the identified plant communities is followed by Matuszkiewicz (2001).

In each association, we looked for plants exhibiting pathological changes. Such symptoms were found in 13 species: Carex acutifomis Ehrh., C. pseudocyperus L., C. riparia Curtis, Eleocharis palustris (L.) Roem. \& Schult., Eupatorium cannabinum L., Glyceria maxima (Hartm.) Holmb., Iris pseudoacorus L., Phalaris arundinacea L., Phragmites australis (Cav.) Trin. ex Steud., Polygonum amphibium L. f. natans Moench, Scirpus ( Schoenoplectus) lacustris L., Sparganium erectum L.em. Rchb., and Typha latifolia L. Additionally, in the patches of the analysed plant associations, submerged dead plant fragments (see Tab. 1 - SDPF) were collected, which were treated jointly, without species distinction, due to identification difficulties. The material in the form of the plants and their dead fragments were subjected to further analysis in the laboratory. Isolation and identification of the phytopathogenic and saprotrophic fungi from tissues of the collected plants was carried out twice. First, immediately after their collection, the plant fragments were incubated in sterile and humid chambers; thereafter, the microorganisms were inoculated onto PDA and CDA media, according to the methods by Kir àly et al. (1977). Supplementary observations and isolations were also carried out within two to four months using 
List of fungus like organisms (FLO) and fungi observed on 13 plant species within rush plant associations around the Lake Glinno

\begin{tabular}{|c|c|c|c|c|c|c|c|c|c|}
\hline & \multirow[b]{2}{*}{ Fungi species } & \multicolumn{7}{|c|}{ Occurrence within plant associations } & \multirow[b]{2}{*}{$\begin{array}{l}\text { Number } \\
\text { of hosts }\end{array}$} \\
\hline & & $C A$ & $C R$ & $E P$ & $G M$ & $P A$ & $\begin{array}{c}P H \\
A R\end{array}$ & $T P$ & \\
\hline 1. & $\begin{array}{l}\text { Acremoniella atra (Corda) } \\
\text { Sacc. }\end{array}$ & & & & & $P A$ & & & 1 \\
\hline 2. & $\begin{array}{l}\text { Acremonium alternatum } \\
\text { Link }\end{array}$ & $P A ; T L$ & & & & & & & 2 \\
\hline 3. & Acremonium sp. & & $G M$ & & & & & $I P$ & 2 \\
\hline 4. & $\begin{array}{l}\text { Acrospermum graminum } \\
\text { Lib. }\end{array}$ & $C A$ & & & & & & $P A$ & 2 \\
\hline 5. & $\begin{array}{l}\text { Alternaria alternata (Fr.) } \\
\text { Keissler }\end{array}$ & $\begin{array}{l}C A ; \\
C P ; P A \\
P A R \\
T L \\
\end{array}$ & $\begin{array}{l}C R \\
G M\end{array}$ & $E P$ & $C A ; E C$ & $P A$ & $\begin{array}{l}P A R \\
E C \\
I P \\
S E \\
\end{array}$ & $\begin{array}{l}P A ; I P \\
C P\end{array}$ & 11 \\
\hline 6. & $\begin{array}{l}\text { Aplanes androgynus } \\
\text { (Archer) Humphrey }\end{array}$ & $C A$ & & & & & & & 1 \\
\hline 7. & $\begin{array}{l}\text { Arthrinium phaeospermum } \\
\text { (Corda)M.B.Ellis }\end{array}$ & & & & & $P A$ & & & 1 \\
\hline 8. & $\begin{array}{l}\text { Arthrinium sporophleum } \\
\text { Kunze }\end{array}$ & $C A$ & & & & & & & 1 \\
\hline 9. & $\begin{array}{l}\text { Arthrobotrys conoides } \\
\text { Drechsler }\end{array}$ & & & & & & $I P$ & & 1 \\
\hline 10. & $\begin{array}{l}\text { Botryotrichum piluliferum } \\
\text { Sacc. } \\
\text { Marchal }\end{array}$ & & & & & & & $P A$ & 1 \\
\hline 11. & Cephalosporium sp. & $P A$ & $I P$ & $E P$ & & $P A$ & & $P A$ & 3 \\
\hline 12. & $\begin{array}{l}\text { Chaetomium globosum } \\
\text { Kunze }\end{array}$ & $C A$ & & & & & & & 1 \\
\hline 13. & Chaetomium sp. & & & & & & & $I P$ & 1 \\
\hline 14. & $\begin{array}{l}\text { Cladochytrium tenue } \\
\text { Nowakowski }\end{array}$ & & $G M$ & & & & & & 1 \\
\hline 15. & $\begin{array}{l}\text { Cladosporium } \\
\text { cladosporioides (Fresen.) } \\
\text { de Vries }\end{array}$ & $\begin{array}{l}P A ; T L \\
C A\end{array}$ & $I P$ & & $E C$ & & & $P A ; I P$ & 5 \\
\hline 16. & $\begin{array}{l}\text { Cladosporium herbarum } \\
\text { Pers.Link }\end{array}$ & $P A$ & $G M$ & & $E C$ & $P A$ & & $I P ; P A$ & 4 \\
\hline 17. & $\begin{array}{l}\text { Clavariopsis aquatica de } \\
\text { Wild. Thornton }\end{array}$ & & & & & & & $I P$ & 1 \\
\hline 18. & $\begin{array}{l}\text { Claviceps microcephala } \\
\text { (Wallr.) Tul. }\end{array}$ & & & & & & & $P A$ & 1 \\
\hline 19. & $\begin{array}{l}\text { Colletotrichum dematium } \\
\text { (Per.) Grove }\end{array}$ & & & & & & & $I P$ & 1 \\
\hline 20. & $\begin{array}{l}\text { Colletotrichum typhae } \mathrm{HC} \\
\text { Greene }\end{array}$ & $T L$ & & & & & & & 1 \\
\hline 21. & Cordella clarkii HB Ellis & & & & & & $C A$ & & 1 \\
\hline 22. & Dactylella arnardii Yadar & & & & & & $I P$ & & 1 \\
\hline 23. & $\begin{array}{l}\text { Dactylella iridis } \\
\text { (T.Wotanabe)Ke Q. } \\
\text { Zhang }\end{array}$ & & & & & & & $I P$ & 1 \\
\hline 24. & $\begin{array}{l}\text { Dasyscyphus controversus } \\
\text { (Cooke) Rehm }\end{array}$ & $T L$ & & & & & & $P A$ & 2 \\
\hline 25. & $\begin{array}{l}\text { Deightoniella arundinacea } \\
\text { (Corda) Hughes }\end{array}$ & $P A$ & & & & & & & 1 \\
\hline 26. & $\begin{array}{l}\text { Doratomyces stemonitis } \\
\text { (Pers.) Morton\&Smith }\end{array}$ & $P A$ & & & & $P A$ & $P A R$ & $I P ; P A$ & 3 \\
\hline 27. & Epicoccum nigrum Link & $C A$ & & & $S L$ & & & & 2 \\
\hline
\end{tabular}


T a b l e 1 cont.

\begin{tabular}{|c|c|c|c|c|c|c|c|c|c|}
\hline 28. & $\begin{array}{l}\text { Fusarium avenaceum (Fr.) } \\
\text { Sacc. }\end{array}$ & & $C R$ & & & & & & 1 \\
\hline 29. & $\begin{array}{l}\text { Fusarium aquaeductuum } \\
\text { (Radlk.et } \\
\text { Rabenh.)Lagerd. }\end{array}$ & & & $E P$ & & & & & 1 \\
\hline 30. & $\begin{array}{l}\text { Fusarium coeruleum Lib. } \\
\text { ex Sacc. }\end{array}$ & $T L$ & & & & & & & 1 \\
\hline 31. & $\begin{array}{l}\text { Fusarium culmorum (W.G. } \\
\text { Smith) Sacc. }\end{array}$ & & & $E P$ & & & & & 1 \\
\hline 32. & $\begin{array}{l}\text { Fusarium equiseti (Corda) } \\
\text { Sacc. }\end{array}$ & & & & & & & $P A$ & 1 \\
\hline 33. & $\begin{array}{l}\text { Fusarium? merismoides } \\
\text { Corda }\end{array}$ & $C A$ & & & & & & & 1 \\
\hline 34. & $\begin{array}{l}\text { Fusarium oxysporum } \\
\text { Schlecht. }\end{array}$ & $C A$ & $\begin{array}{l}G M \\
C A\end{array}$ & $E P$ & & & & $I P$ & 4 \\
\hline 35. & $\begin{array}{l}\text { Fusarium poae (Peck) } \\
\text { Bilaj }\end{array}$ & & & & & $P A$ & & & 1 \\
\hline 36. & $\begin{array}{l}\text { Fusarium sambucinum } \\
\text { Fuckel }\end{array}$ & & & $E P$ & & $P A$ & $C A$ & & 3 \\
\hline 37. & $\begin{array}{l}\text { Fusarium sulphureum } \\
\text { Schlecht. }\end{array}$ & & & & & $P A$ & & & 1 \\
\hline 38. & $\begin{array}{l}\text { Geotrichum candidum } \\
\text { Link. }\end{array}$ & & & & & $P A$ & & & 1 \\
\hline 39. & $\begin{array}{l}\text { Gliocladium roseum } \\
\text { Bainer }\end{array}$ & & & & & & $C A$ & & 1 \\
\hline 40. & $\begin{array}{l}\text { Graphium putredinis } \\
\text { (Corda) Hughes }\end{array}$ & $C P$ & $I P$ & & & & $S E$ & & 3 \\
\hline 41. & Harposporium sp. & & & & & & & $C A$ & 1 \\
\hline 42. & $\begin{array}{l}\text { Hendersonia culmiseda } \\
\text { Sacc. }\end{array}$ & & & & & $P A$ & & & 1 \\
\hline 43. & $\begin{array}{l}\text { Hymenoscyphus herbarum } \\
\text { (Pers. ex Fr.) Dennis }\end{array}$ & & & & & & & $S D P F$ & 1 \\
\hline 44. & Lentinus tigrinus (Bull.Fr.) & & & & & & & $S D P F$ & \\
\hline 45. & $\begin{array}{l}\text { Leptosphaeria caricis } \\
\text { Schrot. }\end{array}$ & & & & & & $C A$ & & 1 \\
\hline 46. & $\begin{array}{l}\text { Leptosphaeria culmifraga } \\
\text { (Fr.) Ces \& de Not }\end{array}$ & & & & & $P A$ & & & 1 \\
\hline 47. & $\begin{array}{l}\text { Leptosphaeria eustoma } \\
\text { (Fuckel) Sacc. }\end{array}$ & & & & & $P A$ & & & 1 \\
\hline 48. & $\begin{array}{l}\text { Leptosphaeria fuckelii } \\
\text { Niessel ex Voss }\end{array}$ & & & & & $P A$ & & & 1 \\
\hline 49. & $\begin{array}{l}\text { Marasmius rotula (Scop.) } \\
\text { Fr. }\end{array}$ & & & & & & & $S D P F$ & 1 \\
\hline 50. & Mollisia caricina Fautr. & $C P$ & & & & & & & 1 \\
\hline 51. & $\begin{array}{l}\text { Monodictys levis } \\
\text { (Wiltshire) S.Hughes }\end{array}$ & $T L$ & & & & & & & 1 \\
\hline 52. & $\begin{array}{l}\text { Monoblepharis? } \\
\text { macrandra (Lagerheim) } \\
\text { Woronin }\end{array}$ & $C A$ & & & $C A$ & & & & 1 \\
\hline 53. & $\begin{array}{l}\text { Morenoina phragmitis } \\
\text { J.P.Ellis }\end{array}$ & & & & & $P A$ & & $P A$ & 1 \\
\hline 54. & $\begin{array}{l}\text { Mucor plumbeus } \\
\text { Bonorden }\end{array}$ & & & & & & & $P A$ & 1 \\
\hline 55. & $\begin{array}{l}\text { Nectriella dacrymycella } \\
\text { (Nyl.) Rehm }\end{array}$ & & & & & & $I P$ & & 1 \\
\hline 56. & $\begin{array}{l}\text { Neottiospora caricina } \\
\text { Desm.Höhn. }\end{array}$ & & $C R$ & & & & & & 1 \\
\hline 57. & Oedocephalum sp. & & & & & $P A$ & & & 1 \\
\hline 58. & $\begin{array}{l}\text { Papulospora byssina } \\
\text { Hudson }\end{array}$ & & & & & $P A$ & & & 1 \\
\hline 59. & $\begin{array}{l}\text { Papulospora sepedonioides } \\
\text { Preuss. }\end{array}$ & & & & & & & $C P$ & 1 \\
\hline 60. & Papulospora sp. & $C A$ & & & & & & & 1 \\
\hline 61. & Periconia atra Corda & $C A$ & & & $C A$ & & & & 1 \\
\hline 62. & Periconia byssoides Pers. & & & & & & & $I P$ & 1 \\
\hline
\end{tabular}


T a b l e 1 cont.

\begin{tabular}{|c|c|c|c|c|c|c|c|c|c|}
\hline 63. & $\begin{array}{l}\text { Periconia cookie } \\
\text { Mason \& M.B.Ellis }\end{array}$ & & & & & $P A$ & & & 1 \\
\hline 64. & $\begin{array}{l}\text { Periconia hispidula (Pers.) } \\
\text { E.W.Mason.\&E.B.Ellis }\end{array}$ & $C A$ & & & $C A$ & & & & 1 \\
\hline 65. & $\begin{array}{l}\text { Periconia minutissima } \\
\text { (Corda) }\end{array}$ & $\begin{array}{l}C A \\
P A\end{array}$ & & & $C A$ & & & IP & 3 \\
\hline 66. & $\begin{array}{l}\text { Phoma arundinacea Berk. } \\
\text { Sacc. }\end{array}$ & & & & & & & $P A$ & 1 \\
\hline 67. & Phoma caricicola Bruner & & $C R$ & & & & & & 1 \\
\hline 68. & Phoma herbarum Westend & & & & & & & $P A$ & 1 \\
\hline 69. & Phoma pseudoacori Brun. & & $I P$ & & & & & $I P$ & 1 \\
\hline 70. & $\begin{array}{l}\text { Phomatospora berkeleyi } \\
\text { Sacc. }\end{array}$ & & & & & $P A$ & & & 1 \\
\hline 71. & $\begin{array}{l}\text { Phyllosticta caricis (Fckl.) } \\
\text { Sacc. }\end{array}$ & $C A$ & & & $C A$ & & & & 1 \\
\hline 72. & $\begin{array}{l}\text { Physoderma gerhardti } \\
\text { Schröter }\end{array}$ & & $G M$ & & & & & & 1 \\
\hline 73. & $\begin{array}{l}\text { Psathyrella typhae } \\
\text { (Kalchbr.) Pears \& } \\
\text { Dennis }\end{array}$ & $T L$ & & & & & & & 1 \\
\hline 74. & $\begin{array}{l}\text { Pseudocecosporella } \\
\text { herpotrichoides (Fron) } \\
\text { Deighton }\end{array}$ & $C A$ & & & $C A$ & & & & 1 \\
\hline 75. & Puccinia caricina DC. & & $C R$ & & & & & & 1 \\
\hline 76. & Puccinia coronata Corda & & $G M$ & & & & & & \\
\hline 77. & Puccinia dioicae Magn. & & & & & & $C A$ & & 1 \\
\hline 78. & $\begin{array}{l}\text { Puccinia magnusiana } \\
\text { Korn. }\end{array}$ & $P A$ & & & & $P A$ & & $P A$ & 1 \\
\hline 79. & $\begin{array}{l}\text { Puccinia phragmitis } \\
\text { (Schum.) Korn. }\end{array}$ & $P A$ & & & & $P A$ & & $P A$ & 1 \\
\hline 80. & $\begin{array}{l}\text { Puccinia polygonii } \\
\text { amphibii Pers. }\end{array}$ & & & & & & $P A M$ & & 1 \\
\hline 81. & Pyrenochaeta sp. de Nortis & & $G M$ & & & & & & 1 \\
\hline 82. & $\begin{array}{l}\text { Pythium debaryanum } \\
\text { Hesje }\end{array}$ & & & & & & & $P A$ & 1 \\
\hline 83. & $\begin{array}{l}\text { Rotula graminis (Desm.) } \\
\text { Crane\& Schoknecht. }\end{array}$ & $\begin{array}{l}C A \\
P A\end{array}$ & $C R$ & $C A$ & & $P A$ & & $P A$ & 3 \\
\hline 84. & $\begin{array}{l}\text { Scirrhia rimosa (Alb. \& } \\
\text { Schw.) Nitschke ex Fuckel }\end{array}$ & $P A$ & & & & & & $P A$ & 1 \\
\hline 85. & $\begin{array}{l}\text { Sclerotinia sulcata } \\
\text { Whetzel }\end{array}$ & & $C R$ & & & & & & 1 \\
\hline 86. & Septoria caricis Pass. & & & & & & & $C P$ & 1 \\
\hline 87. & $\begin{array}{l}\text { Staganospora sacchari Lo } \\
\text { et Ling. }\end{array}$ & $T L$ & & & & & & & 1 \\
\hline 88. & $\begin{array}{l}\text { Torula herbarum (Pers.) } \\
\text { Link }\end{array}$ & & & & & & & IP & 1 \\
\hline 89. & $\begin{array}{l}\text { Trichaegum (Corda) } \\
\text { nodulosum }\end{array}$ & & & & & & & $C P$ & 1 \\
\hline 90. & Ulocladium botrytis Preuss & $C A$ & & & $C A$ & & & & 1 \\
\hline 91. & $\begin{array}{l}\text { Ulocladium chartarum } \\
\text { (Preuss) Simmons }\end{array}$ & $C P$ & & & & & & $T L$ & 2 \\
\hline 92. & Ustilago Davissi Liro & & $G M$ & & & & & & 1 \\
\hline 93. & Ustilago grandis Fr. & & & & & & & $P A$ & 1 \\
\hline 94. & $\begin{array}{l}\text { Verticillium albo atrum } \\
\text { Reinke\&Berth. }\end{array}$ & $C A$ & & & $C A$ & & & & 1 \\
\hline
\end{tabular}

Explanations: $C A \quad$ Carex acutiformis; $C P \quad$ Carex pseudocyperus; $C R \quad$ Carex riparia; EP Eleocharis palustris; EC Eupatorium cannabinum; GM Glyceria maxima; IP Iris pseudocyperus; PAR Phalaris arundinacea; $P A \quad$ Phragmites australis; PAM Polygonum amphibium; SL Scirpus (=Schoenoplectus) lacustris; $S E$ Sparganium erectum; TL Typha latifolia; $S D P F$ submerged dead plant fragments

$C A \quad$ Caricetum acutiformis; $C R \quad$ Caricetum ripariae; $E P \quad$ Elocharietum palustris; $G M \quad G l y c e r i$ etum maximae; $P$ A Phragmitetum australis; $P H A R$ Phalaridetum arundinaceae; TP Thelypteridi Phragmitetum. 
dry material. On both dates, an antibiotic-supplemented medium was used for the first isolation. In the next passages, in order to obtain pure, single-spore cultures, the antibiotic was not used. For taxonomic identification of the fungal isolates, the traits described in the following keys were applied: Barron (1972), Booth (1971), Borowska (1986), Ellis and Ellis (1985), Kochman and Majewski (1973), Kwaśna et al. (1991), and Majewski (1979). Nomenclature of macromycetes was given according to Wojewod a (2003).

In order to determine the similarity of species composition of the fungi found in the analysed rush phytocenoses, the Jaccard similarity coefficient modified by Sörensen (Troj a n 1978) was applied:

$$
\text { S } 100 \frac{2 c}{a+b}
$$

where:

$c$ - number of species common to two associations,

$a-$ number of species in the first association,

$b$ - number of species in the second association.

\section{RESULTS AND DISCUSSION}

The results obtained in this study are an introductory, first in Poland attempt to evaluate the diversity of rush associations in relation to saprotrophic and phytopathogenic fungi that inhabit the plants. On 13 plant species and plant dead fragments, in all the rush associations, 94 taxa of fungi and fungus-like organisms (FLO) were found (Tab. 1). Among the so far identified isolates, the Fungi kingdom species were dominant ( $97.87 \%$ of species), while FLO were sporadic, with $2.12 \%$ of those belonging to Oomycota (Fig. 1). The highest fungal diversity was found in the Thelypteridi-Phragmitetum and Caricetum acutiformis rush associations, where respectively

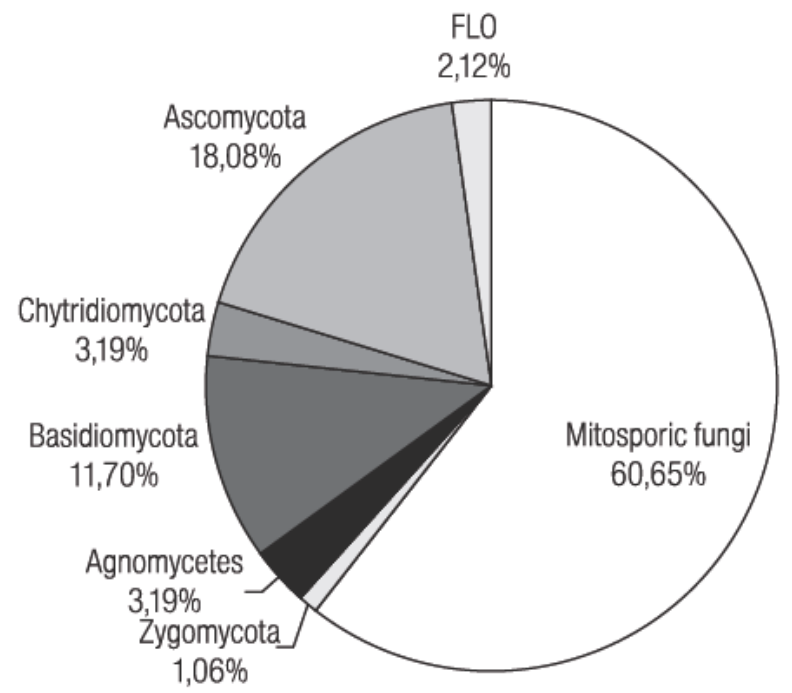

Fig.1. Precentage participation of fungus like organisms and fungi within rush plant associa tions around the Lake Glinno. 


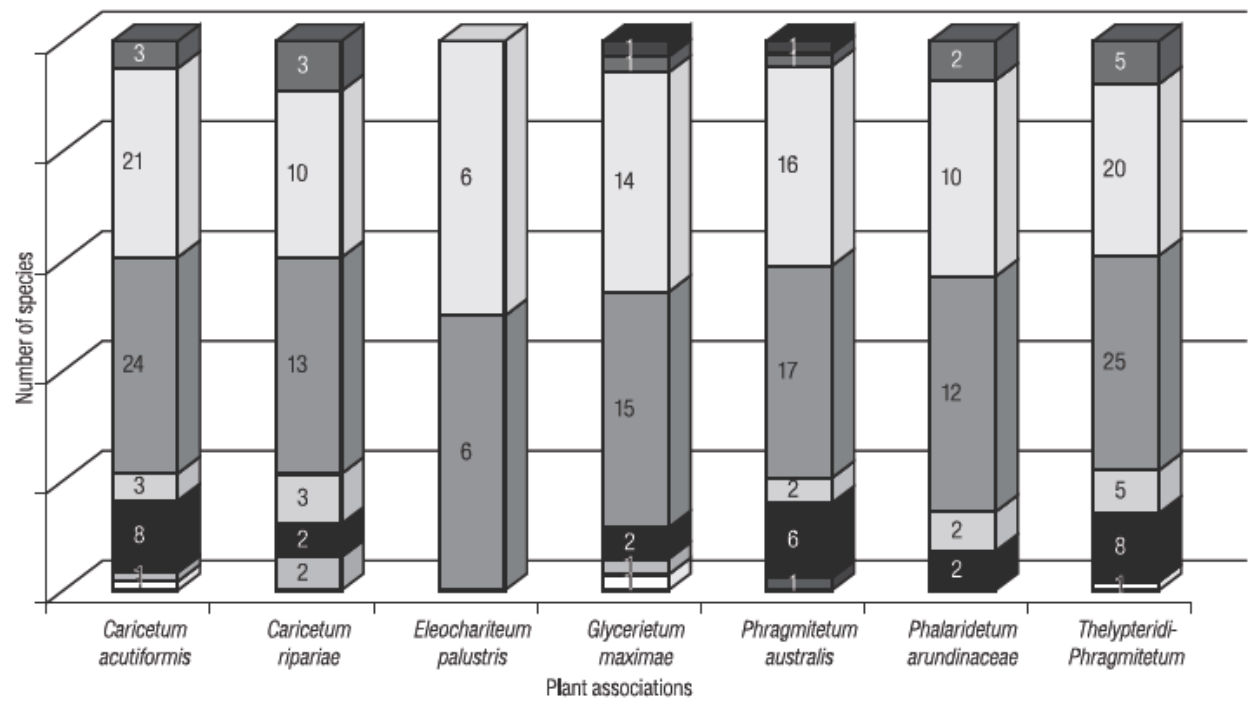

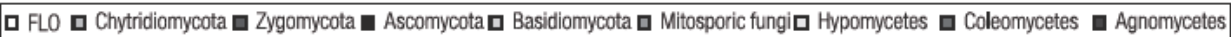

Fig.2. Biodiversity of fungus like organisms and fungi within 7 rush plant associations around the Lake Glinno.

39 and 37 species of FLO and fungi were encountered (Fig. 2). It should be stressed that although a poorer species diversity of fungi (27 taxa) was found in another community, Phragmitetum australis, all the observed species were bound with only one host plant (P. australis). On the whole, in three rush associations that included the common reed, 37 taxa of fungi and FLO were identified on the plant. Pythium debaryanum, an Oomycota organism found on reeds, deserves particular consideration. Biology of this species is tightly connected with aquatic environments. In our studies, the organism was isolated from inside of the stalk, therefore it presumably represented a major cause of weakening and death of reeds. Our research planned for the nearest future will focus on an in-depth enquiry into the frequency of occurrence of Pythium and the threats that the organism poses not only for the common reed. Such a need results from a real danger related to a rising incidence of Pythium found on most of littoral vegetation, which has been recently discovered in Germany (Nechwatal, Mendgen 2005; Nechwatal et al. 2005). The fungal biodiversity observed on $P$. australis within the associations of Phragmitetum australis (27 species) and Thelypteridi-Phragmitetum (24 species) is higher compared to that in the Caricetum acutiformis association (14 species, Tab. 1). This suggests that the floristic diversity of vegetation within an association may not be positively correlated with the diversity of Mycobiota species occurring on a particular host plant species. Our earlier studies on the phyllosphere and caulosphere of reeds in the discussed area revealed 31 species of fungi (Mazurkiewicz-Zapałowicz et al. 2005). According to other studies, taxonomic diversity of microscopic fungi associated with the common reed ranges between 18 (Brandenburger 1985) and 71 species (E1lis, Ellis 1985). There are also works focusing on the occurrence of phytopathogenic species which demonstrate that their diversity on reeds may be limited to $2-4$ taxa 
(Durska 1970; Adamska, Błaszkowski 2001). Due to progressive warming of climate in Europe, the common reed will probably become a host for thermophilic pathogens, which are being observed to spread beyond their original range. This has been already observed by Hyde et al. (1996), who reported Nawawia dendroidea as a new species affecting Phragmites reeds in South Africa.

The host plant association-dependent fungal biodiversity varies also for Carex acutiformis. The sedge hosts from 7 fungal species if found in the Phalaridetum arundinaceae association to 18 fungi if growing in the Caricetum acutiformis association. The specificity of a host plant habitat-dependent fungal biodiversity is determined by dissimilar, local climate and habitat (Andrzejewski, Weigle 2003). The Caricetum acutiformis association plants inhabit open, windy sites, which facilitate migration of fungal spores; on the other hand, Thelypteridi-Phragmitetum and Phalaridetum arundinaceae associations are situated in hollows or inlets, which provides some spatial isolation and restricts spore propagation.

Besides ecological factors, preferences of microorganisms (primarily saprotrophic ones) in relation to host plants may reflect differences in morphology and anatomy of the latter group. Namely, it has been observed that two plant species related to each other, which might be similar as hosts for a number of saprotrophic fungi, do not provide equally attractive substrates. To support this, as few as one fourth of the number of fungi hosted by C. acutiformis were found on C. pseudocyperus, all within the associations that these plants create together (Tab. 1). These differences probably result from dissimilar ways in which that associations are formed by the compared sedge species. C. pseudocyperus does not send runners, thus it occurs in small tufts scattered across the patches of the association. Moreover, its plants are nearly half the size of those of $C$. acutiformis or $P$. australis, which to a large extent protects against spores, especially those of less common fungi. Hence, phytopathogenic fungi observed sporadically in the littoral zone: Pseudocercosporella herpotrichioides and Phyllosticta caricis were actually found on C. acutiformis. Likewise, epiphytic foliage infection by Puccinia dioicae was found only on C. acutiformis. Conversely, another rust species, Puccinia caricina, was identified on C. riparia, the largest sedge species found in Poland. None of the Uredinales order species has been so far observed on C. pseudocyperus, whereas Septoria caricis, which causes chlorotic or necrotic leaf blotching, is a common phytopathogen to C. pseudocyperus. This implies that this sedge has by itself extended the range of $S$. caricis host plants known so far, as this pathogen has been so far isolated only from other sedge species (Ellis, Ellis 1985).

An interesting diversity was found among the fungal species that are characteristic of Iris psudoacorus. Out of 19 fungal taxa associated with this host plant, only 5 were found in the Caricetum ripariae association, whilst as many as 14 species - in Thelypteridi-Phragmitetum. This shows that the health condition of I. psudoacorus in the analysed patches of Thelypteridi-Phragmitetum associations was much poorer, especially as the fungi isolated from these plants were dominated by leaf blotching-causing species: Clavariopsis aquatica, Colletotrichum dematium and Dactylella iridis (Tab. 1). However, Phoma pseudoacori was the most significant phytopathogen of $I$. pseudoacorus, most frequently isolated from large and fuzzy leaf lesions. We have also isolated this species from sporadic plants of the Caricetum ripariae associa- 
tion. Other authors also report Phoma pseudoacori as a frequent cause of necroses (Brandenburger 1985).

Scarce are the data on the incidence of Fusarium oxysporum infecting rush vegetation. This species is most often reported to cause plant fusarioses ( a cicow a 1975; 1977; Łacicowa, Kiecana 1980; Mańka, Frużyńska-Jóźwiak 1989; Kwaśna et al. 1991; Saniewska, Wach 2003). It is therefore worth mentioning that $F$. oxysporum in our studies was isolated from the stalks and leaves of so far unknown host plants: I. pseudoacorus, C. acutiformis, Eleocharis palustris, and Glyceria maxima. On the other hand, studies are continued that focus on physiological diversification and virulence of various strains of this species coming from various rush plants. In relation to zoosporic fungi, Physoderma gerhardii and Cladochytrium tenue, it is recognised that these species are non-specialised endoparasites of leaves. Various species of aquatic and wetland vegetation can become host organisms of these phytopathogens (Skirgiełło 1954; Brandenburger 1985); in the studied area, however, these fungi have been so far found only on Glyceria maxima, especially on the plants growing in the centres of the communities. On the littoral skirts, on the other hand, the dominant G. maxima leaf pathogens were Puccinia coronata and Ustilago davisii. In the Glycerietum maximae association, Typha latifolia was the accompanying species to $G$. maxima. This plant species was commonly infested by Colletotrichum typhae, which resulted in large blotches on the leaves, orange-brown in the centre surrounded by a dark-brown edge.

Based on the Jaccard-Sörensen coefficient the highest mycological similarity among rush plant associations was observed between Caricetum acutiformis with Glycerietum maximae (50\%) whereas the lowest values of that coefficient represented Glycerietum maximae and Phalaridetum arundinaceae rush associations (7\%) (Tab. 2). Evidently lower but comparable values of mycological similarity were observed between Thelypteridi-Phragmitetum and Caricetum ripariae (26\%), Caricetum ripariae and Eleocharitetum palustris (25\%), Eleocharitetum palustris and Glycerietum maximae (24\%), Thelypteridi-Phragmitetum and Caricetum acutiformis (23\%),

Table 2

Diagram of mycological similarity of distinguished rush plant associations around Lake Glinno

\begin{tabular}{|c|c|c|c|c|c|c|c|}
\hline $\begin{array}{c}\text { Plant } \\
\text { association }\end{array}$ & $\mathrm{T} \mathrm{P}$ & $\mathrm{C} \mathrm{A}$ & $\mathrm{C} \mathrm{R}$ & $\mathrm{G} \mathrm{M}$ & $\mathrm{P} \mathrm{A}$ & $\mathrm{E} \mathrm{P}$ & PH AR \\
\hline $\mathrm{T}$ P & $\mathrm{X}$ & $23 \%$ & $26 \%$ & $13 \%$ & $22 \%$ & $14 \%$ & $11 \%$ \\
\hline $\mathrm{C} \mathrm{A}$ & & $\mathrm{X}$ & $16 \%$ & $50 \%$ & $15 \%$ & $10 \%$ & $12 \%$ \\
\hline $\mathrm{C} \mathrm{R}$ & & & $\mathrm{X}$ & $14 \%$ & $11 \%$ & $25 \%$ & $18 \%$ \\
\hline $\mathrm{G} \mathrm{M}$ & & & & $\mathrm{X}$ & $13 \%$ & $24 \%$ & $7 \%$ \\
\hline P A & & & & & $\mathrm{X}$ & $16 \%$ & $17 \%$ \\
\hline E P & & & & & & $\mathrm{X}$ & $18 \%$ \\
\hline PH AR & & & & & & & $\mathrm{X}$ \\
\hline
\end{tabular}

Explanations see Tab. 1 
Thelypteridi-Phragmitetum and Phalaridetum arundinaceae (22\%) rush plant associations.

Lack of comparable studies in Western Pomerania, as well as scarce literature published in Poland dealing with fungi of rush associations (Durska 1970; Mułenko 1989; Adamska, Błaszkowski 2000) result in the fact that a range of fungal species found on the plants that constitute these communities are their first observations in Poland. This is not due to the rarity of these species, but is rather a result of low interest in the subject and a fragmentary, local recognition of biodiversity. Therefore, similar studies are intended to be carried out over the next years, also in the rush associations of other lakes located within Western Pomeranian province.

A comparison of fungal diversity between all rush communities yields an interesting diversification in taxonomic groups of fungi. It has been demonstrated that among Mycobiota the most numerous taxa belong to mitosporic fungi, or Coleomycetes class (11 taxa) and Hyphomycetes (46 taxa). These species (57 taxa) represent $60.64 \%$ of the total taxonomic diversity. Ascomycota fungi (17 species) and Basidiomycota fungi (11 species) represent, respectively, $18.08 \%$ and $11.70 \%$ of the total fungal biodiversity. Chytridiomycota ( 3 species, 3.19\%), Zygomycota (1 species, $1.06 \%$ ), and - included into FLO - Oomycota ( 2 species, $2.12 \%$ ), were found sporadically. These values are also reflected in the proportions of the fungal diversity in the plant associations: all the associations are dominated by mitosporic fungi (Fig. 2). Thus, the fungal diversity of the phyllo- and caulosphere are primarily formed by Hyphomycetes and Coleomycetes fungi. Similar trends in relation to other host plants have been confirmed by Cwalin a-A mbroziak et al. (2000). Fusarium species are the most frequently found Hyphomycetes fungi in the studies area. These microorganisms belong to the so-called facultative parasites, which in adverse growth conditions and with weak plants can become the primary causes of pathological changes (Langerfeld 1971; Lacicowa 1979; Seppänen 1981; Chełkowski, Mańka 1983; Mańka et al. 1985; Chełkowski et al. 1989; Kwaśna et al. 1991). According to our study, this probably concerns Eleocharis palustris. Besides F. oxysporum, also three other Fusarium species were isolated from brown lesions located under the ear of the plant, namely F. aquaeductuum, F. culmorum, and F. sambucinum. Further studies are needed to establish which of these species form the main cause of the rot lesions found on the plants and which are only an accompanying factor. Complex and common occurrence of Fusarium species was also observed for $P$. australis. If we discuss this particular host plant, Fusarium poae is a species specially worth mentioning; according to Booth (1971), the fungus is responsible for plantlet fusarioses, malformations and withering of inflorescence in various plants of the family Graminae. Not only do Fusarium spp. affect the health of rush vegetation they live on, especially $P$. australis and G. maxima, they are also significant due to their intense toxin-producing activity. Namely, a real danger of poisoning arises due to an increasingly common use of $P$. australis as a housing construction material (roof cladding) or G. maxima as a livestock feed; this way either humans or livestock animals may become exposed to Fusarium toxins, especially those of the trichothecinforming group (Chełkowski 1985). Saprotrophic Alternaria, Cladosporium, and Doratomyces fungi, commonly found on all rush vegetation species, represent another health hazard for people. Their strains isolated from various indoor bioaerosols 
has been demonstrated to have an allergenic health effect ( $\mathrm{Zaw}$ is za 2001). Since reed is harvested in spring, the growth of saprotrophic fungi is particularly intensive. Other fungal species, Deigtoniella arundinacea, Puccinia magnusiana, P. phragmitis, and (sporadically) Ustilago grandis, lead to significant starvation and weakening of plants. This in turn has an economic aspect, since the pathogens cause biomass losses (Durska 1970; Tanaka 1991).

The continuation of these studies planned for the following years will presumably allow us to extend the list of the species associated with rush vegetation, and will also enable evaluation of the local significance of particular pathogens. Constant monitoring of fungal biodiversity and, thus, permanent health inspection of rush associations in Western Pomerania seems to be of particular importance, since large areas of waste land covered with reed beds are being assigned for reed cultivation (Friedrich, Jasnowska 2003; Rogalski et al. 2004). Besides, large-area rush phytocenoses represent a characteristic landscape element of riverine valleys and banks of lakes and streams (Ostendorp 1993; Boszke et al. 2005).

\section{REFERENCES}

Adamska I., Błaszkowski J. 2000. Microscopic fungus like organisms and fungi of the Słowiński National Park. I. Acta Mycol. 35(2): 243259.

Andrzejewski R., Weigle A. 2003. Różnorodność biologiczna Polski. Drugi polski raport 10 lat po Rio. Narodowa Fundacja Ochrony Środowiska, Warszawa.

B a r ro n G.L. 1972. Of Hyphomycetes from soil. R.E. Krieger Publishing Company.

B o o th C. 1971. The genus Fusarium. Commonw.Mycol.Inst., Kew. Surrey.

Borowska A. 1986. Flora Polska. Grzyby (Mycota) 16: Deuteromycetes, Hyphomycetes, Dematiaceae Phialoconidiae. PWN, Warszawa Kraków.

B os i a ck a B., R a dziszewicz M. 2002. Roślinność oczek wodnych i wilgotnych zagłębień śródpolnych w okolicach Karlina (Pomorze Zachodnie). Bad. Fizjogr. Pol. Zach. Seria B, 51: 83101.

Boszke P., Bociąg K., Szmeja J. 2005. Population structure and regeneration of Phragmites australis (Cav.) Trin. ex Steud. in flood control ditches in the depression wetland (Żuławy Wiślane, northern Poland). Pol. J. Ecol. 53(1): 312.

Brandenburger W. 1985. Parasitische Pilze an Gefäßpflanzen in Europa. Gustav Fischer Verlag, Stuttgart New York.

Chełk owski J. 1985. Mikotoksyny, wytwarzające je grzyby i mikotoksykozy. Wyd. SGGW AR, War szawa.

Chełkowski J., Mańka M. 1983. The ability of Fusaria pathogenic to wheat, barley and corn to pro duce zearalenone. Phytopath. Z. 106: 354359.

Chełkowski J., Mańka M., Kwaśn a H., Visconti A., Goliński P. 1989. Fusarium sporotrichio ides Sherb., Fusarium tricinctum (Corda) Sacc. and Fusarium poae (Peck) Wollenw. Cultural charac teristics, toxinogenicity and pathogenicity towards cereals. J. Phytopathol. 124:155 161.

Cwalina Ambroziak B., Kowalska E., Gronowicz Z. 2000. Zbiorowiska grzybów fyllosfery ziemniaka w zależności od wybranych warunków agrotechnicznych. Zesz.Probl. Post.Nauk.Rol. 478:123 128.

D u r sk a B. 1970. Changes in te reed (Phragmites communis Trin.) condition caused by diseases of fungal and animal origin. Pol. Arch. Hydrobiol. 17 (30): 373396.

Ellis M., Ell is J.P. 1985. Microfungi on land plants. An identification handbook. Macmillan Publishing Company, New York.

Friedrich S., J a n ow ska J. 2003. Próba rozwiązania problemu ochrony gatunkowej roślin na prywat nych użytkach rolniczych na przykładzie Bagien Rozwarowskich (Pomorze Zachodnie). Chronmy Przyr. Ojcz. 59 (2): 99104.

Hyde K.D., Go h T.H., Ste in ke T. 1996. Nawawia dendroidea, a new synnematous hyphomycete from submerged Phragmites in South Africa. Mycol. Res. 100 (7):810 814.

Király Z., Klement Z., Solymosy F., Vörös J. 1977. Fitopatologia. Wybór metod badawczych. PWRiL, Warszawa. 
Kochman J., Majewski T. 1973. Flora Polska. Grzyby (Mycota) 5: Basidiomycestes, Ustilaginales. PWN, Warszawa Kraków.

Kreft A., Tru ch an M. 1996. Zespoły roślinne strefy brzegowej Jeziora Łętowskiego w województwie słupskim. Bad. Fizjogr. Pol. Zach. Seria B, 45: 167180.

Kwaśn a H., Chełkowski J., Zajk kows ki P. 1991. Flora Polska. Grzyby (Mycota) 22: Deuteromycetes, Hyphomycetes, Tuberculariaceae, Fusarium. PWN, Warszawa Kraków.

Langerfeld E. 1971. Unterschiedliche Eigenschaften in der Pathogenität von zwei Kartoffelfäuler regern aus der Gattung Fusarium Lk. Nachrichtenbl. Dtsch. Pflanzenschutzdienstes (Braunschw.). 23 (11): 168169.

Ła ci cow a B. 1975. Fuzarioza lnu (F. oxysporum f. lini) na Lubelszczyźnie. Ochr. Rośl. 3: 912.

Łacicowa B. 1977. Badania nad podatnością różnych odmian lnu na fuzariozę (F. oxysporum f. lini). Tezy do referatów na XVIII Sesję Naukową IOR, Poznań: 2122.

Łacicowa B. 1979. Ocena laboratoryjna wirulencji szczepów Fusarium oxysporum f. lini i Fusarium oxysporum f. phaseoli oraz podatności odmian na porażenie przez te patogeny. Rocz. Nauk Rol. ser. E, 9, 1: 113124.

Łacicowa B., Ki e ca n a I. 1980. Zgorzel naczyń koniczyny czerwonej (Trifolium pratense L.) powodo wana przez F. oxysporum f. sp. trifolii (Jancz.) Biłaj. Rocz. Nauk Rol. ser. E, 10, 1 2: 145161.

Majewski T. 1979. Flora Polska. Grzyby (Mycota) 11: Basidiomycetes, Uredinales II. PWN, Warszawa Kraków.

Mańka M., Frużyńska Jóźwiak D. 1989. An attempt of biological control of glasshouse carnation Fusarium wilt. Acta Hort. 225: 281285.

Mańka M., Visconti A., Chełkowski J., Bottalico A. 1985. Pathogenicity of Fusarium isolates from wheat, rye, and triticale towards seedlings and their ability to produce trichothecenes and zearalenone. Phytopath. Z. 113: 2429.

Marks M., R and all J. 1994. Phragmites australis (P.communis): threats, management and monitoring. Natl. Areas J. 14: 285294.

Matuszkiewicz W. 2001. Przewodnik do oznaczania zbiorowisk roślinnych Polski. Ser. Vademecum Geobotanicum 3. PWN, Warszawa.

Mazurkiewicz Zapałowicz K., Janowicz K., Wolska M., Słodownik A. 2005. Bioróżno rodność gatunkowa grzybów mikroskopowych trzciny pospolitej (Phragmites australis (Cav.)Trin.ex Steud.) w zbiorowiskach szuwarowych Jeziora Glinno. Acta Agrobot. 58(2): 359368.

Mułenko W. 1989. Mikroskopowe grzyby fitopatogeniczne Pojezierza Łęczyńsko Włodawskiego II. Acta Mycol. 24(2): 125171.

Nechwatal J., Mendgen K. 2005. Pythium litorale sp.nov., a new species from the litoral of Lake Konstance, Germany. FEMS Microbiology Letters. 255: 96

Nechwat al J., Wielgoss A., Mendg en K. 2005. Pythium phragmitis sp. nov., a new species clone to P. arrhenomanes as a pathogen of common reed (Phragmites australis). Mycol. Res. 109: 13371346.

Ostendorp W. 1993. Reed bed characteristics and significance of reeds in landscape ecology. Act. Limnol. 5: 149161.

Rogalski M., Kwarta Cz., Trzaskoś M. 2004. Naturalistic qualities and economic values of rush communities inhabitating periodically flooded peat soils in the river Rurzyca valley. (In:) L. Wołej ko and J. J a snowska (eds). The future of Polish mires. Monogr. AR in Szczecin: 251256.

S a niews ka A., Wa ch I. 2003. Rozwój fuzariozy powodowanej przez Fusarium oxysporum f.sp. tulipae na odmianach tulipanów potencjalnie wrażliwych i odpornych na tworzenie się gum na cebulach. Post. Ochr. Rośl./ Prog. Plant Prot. 43 (2): 898900.

Seppänen E. 1981. Fusariums of the potato in Finland. I. On the Fusarium species causing dry rot in potatoes. Ann. Agric. Fenn. Ser. Phytopathol. 20 (2): 156160.

Skirgi ełło A. 1954. Grzyby niższe. Pragrzyby i Glonowce. PWN, Warszawa.

Szafe r W., Zar zy cki K. 1977. Szata roślinna Polski. II. PWN, Warszawa.

Szczepański A. J. 1978. Ecology of macrophytes in wetlands. Pol. Ecol.Stud. 4: 4594.

Tanaka Y. 1991. Microbial decomposition of reed (Phragmites communis) leaves in a saline lake. Hydrobiologia 220: 119129.

Troj a n P. 1978. Ekologia ogólna. PWN, Warszawa.

To ma szewicz H. 1978. Roślinność wodna i szuwarowa Polski (Klasy: Lemnetea, Charetea, Potamogeto netea, Phragmitetea) wg stanu zbadania na rok 1975. Rozpr. Uniw. Warsz. 
Woje wo da W. 2003. Checklist of Polish larger Basidiomycetes. (In:) Z. Mirek (ed.). Biodiversity of Poland 7. W. Szafer Insitute of Botany, Polish Academy of Sciences, Kraków.

Wołej k o L. 2000. Roślinność szuwarowa i turzycowiskowa z klasy Phragmitetea kompleksów źródlisko wych Polski północno zachodniej. Folia Univ. Agric. Stetin. 213 Agricultura (85): 221246.

Zaw is za E. 2001. Grzyby a choroby alergiczne. Nowa Medycyna 109 (1): 1115.

\section{Z badań grzybów fitopatogenicznych \\ i saprotroficznych w zbiorowiskach szuwarowych Jeziora Glinno}

\section{Streszczenie}

W badaniach prowadzonych w latach 20042005 stwierdzono występowanie 94 gatunków grzybów i organizmów grzybopodobnych (OGP) na 13 gatunkach roślin, występujących w siedmiu zespołach szuwarowych wokół Jeziora Glinno. Z fragmentów roślin wykazujących objawy chorobowe izolowano zarówno gatunki fitopatogeniczne z rodzajów: Puccinia, Usti lago, Leptosphaeria, Septoria, Fusarium, Pythium i in. jak i powszechnie obecne saprotrofy rodzajów: Alternaria, Cladosporium, Doratomyces, Periconia, Rotula i in. Największe zróżnico wanie gatunkowe stwierdzono wśród grzybów mitosporowych i Ascomycota, które stanowiły odpowiednio $61,63 \%$ i 18,08\% wszystkich gatunków. Sporadycznie stwierdzano gatunki Chy tidiomycota, Oomycota i Zygomycota. Największa bioróżnorodność mikologiczna charakte ryzowała Phragmites australis (37 gatunków grzybów), Carex acutiformis (25 gatunków) i Iris pseudoacorus (19 gatunków). 
